\title{
Deforming-bed origin for southern Laurentide till sheets?
}

\author{
Richard B. Alley \\ Earth System Science Center and Department of Geosciences, The Pennsylvania State University, \\ University Park, Pennsylvania 16802, U.S.A.
}

\begin{abstract}
The widespread, uniform till sheets of the southern margin of the Laurentide ice sheet were deposited by fast-moving, wet-bedded ice over relatively short periods of time. Characteristics of these till sheets are entirely consistent with deposition from deforming subglacial sediment layers; it is difficult (although not impossible) to explain their origin through debris transport in basal ice. Careful estimation of debris budgets and studies of sorted sediments contained in the till sheets may clarify their origin further.
\end{abstract}

\section{INTRODUGTION}

Mid-latitude Pleistocene glacial drift has been studied intensively, but we still do not fully understand how the ice eroded, transported and deposited this material. Interest in this question has increased recently with speculation that subglacial deformation of unconsolidated sediments contributed to or dominated ice motion and sediment budget, especially along parts of the southern margin of the late Wisconsinan Laurentide ice sheet. Discussion now focuses on whether the southern Laurentide till sheets primarily reflect debris transport within or beneath glacial ice.

I have been studying subglacial deformation from a glaciological standpoint, and particularly as it relates to motion of modern West Antarctic ice streams. Here I use the results of my theoretical and literature studies of subglacial deformation to address the origin of southern Laurentide till sheets. I find that a deforming-bed origin is likely, but that no unequivocal conclusion is possible with present knowledge.

Below, I first describe the till sheets under consideration. I then present end-member models for debris transport in and beneath ice, and ask which model best matches the observations. Throughout, the reader should remember that debris transport probably occurred both in and beneath the ice; I seek to learn which, if either, was dominant.

For convenience, I refer generically to tills of the southern margin of the Laurentide ice sheet. However, the evidence I cite is most applicable to characteristics and depositional conditions of tills deposited by fast-moving, late Wisconsinan ice flowing out of Lake Michigan into Illinois, U.S.A. Tills of similar age in Ohio, Indiana, the Des Moines and James lobes of Iowa and South Dakota, U.S.A., and other regions with fast ice motion over thawed beds may be similar, but the evidence is not as strong. Tills deposited in a similar manner may also occur north of the Great Lakes on the Canadian Shield (Hicock and others, 1989).

It is also important to remember that, although I have seen some of the deposits in question, I have done no original work on them. I am thus trying to explain the origin of the till sheets as they appear in the literature, an exercise that is valid only insofar as my reading of the literature is correct and the literature reflects true field conditions.

Formal and informal reviewers with vast field experience have cited features (e.g. glacial thrust blocks in the North American prairies, tunnel valleys in Wisconsin, U.S.A.) that fall outside of the discussion here. These colleagues have also emphasized that no real glacial deposit is likely to be as simple as my descriptions here, or to approach closely any of my end-member depositional models. I find it gratifying that so many problems remain to be explored, and I defend my oversimplifications solely by appealing to the pragmatic need to start somewhere.

Here I use "deforming till" and "deforming bed" to refer to subglacial sediments undergoing pervasive shear deformation to large strains; such sediments are expected to be glacially produced diamictons, as emphasized by the term "deforming till". The sediment becomes "deformation till" when it ceases to deform. Please notice that the term "deforming till" is an informal term, which is not approved by the Till Work Group of the Commission on Genesis and Lithology of Glacial Quaternary Deposits of the International Union for Quaternary Research (INQUA) (Dreimanis, 1989). 


\section{TILL OBSERVATIONS}

Parts of the southern margin of the Laurentide ice sheet from Ohio to the Great Plains of the U.S.A and Canada deposited widespread basal till units as gently rolling till plains; deposits of the Lake Michigan lobe may be typical. As summarized by Kemmis (1981, 1986), Beget (1986), Sharpe (1986), and Clayton and others (1987, 1989), among others, these basal tills:

1. are matrix-dominated;

2. commonly lack observable deformation indicators (folds, boudinage, etc.);

3. exhibit sharp basal contacts with undeformed or weakly deformed sub-till sediments;

4. are overconsolidated;

5. sometimes contain limited sorted sediments, some with primary depositional features;

6. are characterized by uniform matrix properties, except: (a) locally derived material decreases upwards, and (b) occasional block inclusions of older substrate materials occur, which are commonest and often are deformed near the till base;

7. occur as sheet-like deposits $\approx 1-10 \mathrm{~m}$ thick and several hundred to a few thousand square kilometers.

Stratigraphically (Kemmis, 1981; Wickham and Johnson, 1981; Wickham and others, 1988; Clayton and others, 1989):

8. a large number of till members are recognized, each with lithologically distinct basal tills;

9. these till members occur in a well-defined stratigraphic sequence, and only the base of the lowermost till is consistently in contact with bedrock.

Glaciologically, the evidence of glacial geology shows that the depositing ice (Wright, 1973; Mathews, 1974; Mickelson and others, 1981, 1983; Clayton and others, 1985; Beget, 1986; Clark and Lillie, 1989):

10. was fast-moving $\left(\approx 100-1000 \mathrm{~m} \mathrm{a}^{-1}\right)$ (although the ice motion may have slowed or stopped prior to deposition);

11. was wet-bedded;

12. exerted low basal shear stresses $(\approx 5-$ $50 \mathrm{kPa}=0.05-0.5$ bar);

13. was present for a relatively short time $(\approx 100$ $1000 \mathrm{a} /$ till member).

The mechanisms of transport and deposition responsible for the uniformity, differentiability, and widespread occurrence of these till sheets are not known, although several candidates exist. The possible mechanisms of erosion and entrainment include subglacial deformation, and basal (i.e. debris occurring within the ice near the bed) transport through shearing-in, net freezing-on, or regelation. Transport may have occurred by any or all of subglacial deformation (pervasive or discrete), sliding of dirty ice over its substrate, ploughing (a transitional state between sliding and bed deformation (Brown and others,
1987)), and internal deformation of dirty basal ice, with a minor contribution from englacial transport farther from the bed. Deposition may have occurred through cessation of subglacial deformation, or through debris loss from ice by regelation, smearing-on of clasts (lodgement), or stagnation of ice (the entire mass or only the dirty basal layer) and subsequent melt-out. Subglacial streams are important agents of erosion, transport, and deposition, but produce sorted sediments clearly different from tills. Subglacial water storage and catastrophic drainge (e.g. Attig and others, 1989; Shaw and others, 1989) might produce diamictons, but will also produce recognizable sorted sediments, and the indicators of such castrophic drainage do not seem to occur south of Lake Michigan. I thus ignore these possiblities here.

\section{DEFORMING BED MODEL}

As developed in earlier publications (e.g. Alley and others, 1986; Boulton and Hindmarsh, 1987; Clarke, 1987; Alley, 1989a,b; and references therein), the deforming-bed model can be summarized as follows:

high ice velocities $\left(>\approx 100 \mathrm{~m} \mathrm{a}^{-1}\right)$ with low basal shear stresses $(\approx 10 \mathrm{kPa})$ require thawed beds with high, saturated porosity and high basal water pressures. (The relatively rapid deformation of a thin layer of debris-rich ice at or very close to the melting point observed by Echelmeyer and Zhongxiang (1987) did not yield high ice velocities, and a sufficiently thick and soft layer of such dirty ice to yield high velocities almost certainly would develop enough heat from viscous dissipation to remove the interstitial ice.) Bed deformation requires reduction of clast-clast contact forces, achieved by water pressure almost equal to overburden pressure. Rapid sliding requires smoothing and lubrication of the bed by water, which requires that the water pressure exceed the local ice pressure over a significant fraction of the bed (Weertman, 1964; Alley, 1989a);

basal velocities from active processes (sliding, bed deformation, ploughing) are additive (Fig. 1); all other things being equal, a given velocity in the absence of bed deformation requires a higher basal water pressure (to increase ice-bed separation across a discontinuous water layer and thus increase sliding velocity, or to decrease strength in the surface layer of the bed and thus increase ploughing velocity) than does the same velocity with pervasive bed deformation (Boulton and Hindmarsh, 1987; Alley, 1989a, b);

if a large, wet-based ice sheet lacks channelized drainage of surficial meltwater to the bed, lacks episodic storage and release of subglacial meltwater through channels, and has basal generation of water in excess of subglacial aquifer capacity, it will develop a distributed, high-pressure water system at the ice-bed interface; such a situation should be common under large ice sheets (Weertman, 1972; 


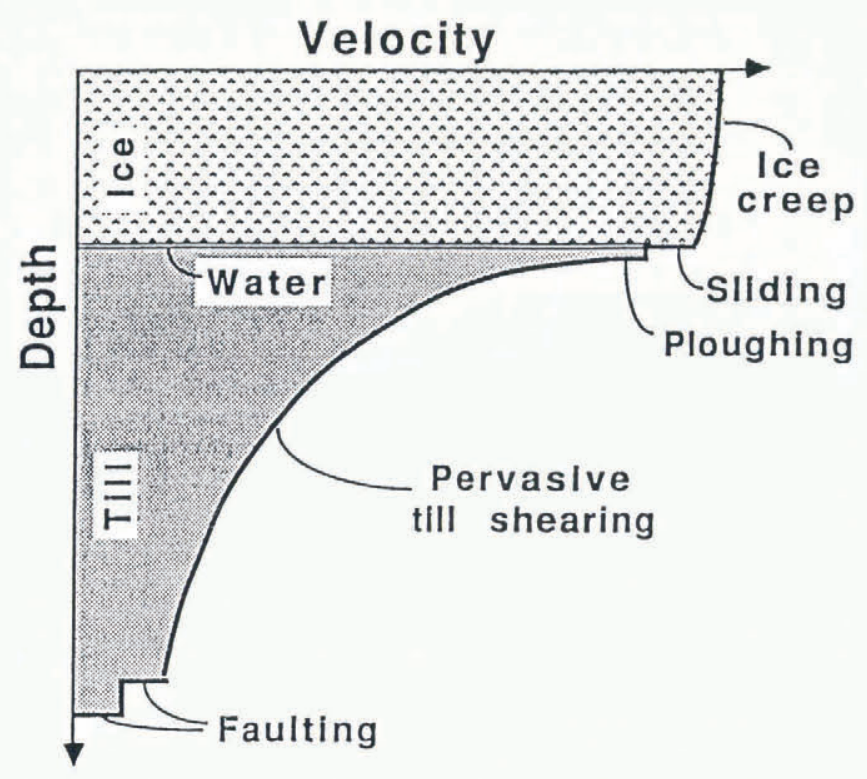

Fig. 1. Cartoon of possible mechanisms causing ice velocity. For fast-moving, wet-based ice on unconsolidated sediment, pervasive till shearing is likely to provide most of the velocity (Alley, 1989b).

Alley and others, 1987a; Blankenship and others, 1987; Alley, 1989a);

if subglacial materials are unconsolidated or poorly consolidated, such high water pressures will cause pervasive deformation to a depth of up to $10 \mathrm{~m}$ even for relatively low basal shear stresses (Alley and others, 1987a, b; Boulton and Hindmarsh, 1987; Fahnestock and Humphrey, 1988; Blake and Clarke, 1989; Meier, 1989);

such pervasive subglacial deformation will account for most of the ice velocity if water pressures are high, basal shear stresses are low, and the deforming layer is $\approx 0.1 \mathrm{~m}$ thick or thicker. Discrete shearing beneath the deforming layer and ploughing and sliding at the top of the deforming layer are likely, but are unlikely to account for most of the ice velocity. In particular, sliding over unconsolidated sediments is likely to be slow, because such materials are typically quite rough compared to glacially polished bedrock (Engelhardt and others, 1978; Boulton and Hindmarsh, 1987; Brown and others, 1987; Alley, 1989b), although smooth, unconsolidated sediments are theoretically possible;

if moulin-fed channels reach a deforming bed and remain open, then regions near the channels will experience low water pressures, and sediment transport will occur by sediment creep to channels and by water transport in channels; regions farther from channels (if channels are sufficiently far apart) will behave as if there are no channels (Alley, 1988b, paper in preparation).

\section{BASAL-TRANSPORT MODEL}

The end-member model for basal transport without bed deformation, as discussed in any good textbook on glacial geology (e.g. Sugden and John, 1976), can be summarized as follows:

materials beneath ice are rigid (or nearly so);

ice velocity arises from sliding between ice and substrate or from deformation within ice; high velocities $\left(>\approx 100 \mathrm{~m} \mathrm{a}^{-1}\right.$ ) under low shear stresses $(\ll 100 \mathrm{kPa})$ require fast sliding and high basal water pressures over saturated subglacial materials or impermeable substrates; sliding velocity increases with water pressure (Alley, 1989a);

material is incorporated into the basal ice by a number of processes, including: (a) shearing-in or folding-in of debris along fault planes, shear zones, or fold axes in zones of compressive flow, including over-riding of frontal, stagnant debris-rich ice; (b) net freezing-on of debris owing to cooling of a thawed bed; and (c) regelation, which can trap small particles in the course of pressure melting and refreezing during ice motion around obstacles (notice that the English usage of "regelation" is very restricted, referring to a process driven by pressure differences in which melting and refreezing balance, with the heat required for melting supplied by the heat released by refreezing. "Regelation" is occasionally used for "multigelation", any oftenrepeated freezing and thawing (Bates and Jackson, 1980 ), but this usage is imprecise and should be avoided);

material is deposited from ice by: (a) regelation, which can release fine clasts from the ice where pressure melting occurs; (b) net melt-out from stagnant ice, whether the stagnant zone is the entire ice thickness or a basal layer that has ceased to participate in the main ice flow; (c) lodgement, the clast-by-clast smearing of particles on to the glacier bed, caused by net basal melting or layer thinning (extensional flow) moving clasts toward the bed and clast-bed friction retarding clast motion; lodgement probably involves both regelation and net melt-out from active ice;

a transitional state between sliding and bed deformation may exist in which ice moves over clasts that themselves "plough" through the upper layer of an otherwise rigid substrate (Brown and others, 1987). (The ploughing model of Brown and others can clearly be generalized to motion within or beneath deforming sediments, but here I restrict it to the original usage describing the ice-sediment interface.)

The deforming-bed and basal-transport models presented here are believed to encompass most processes of transport and deposition of tills beneath glaciers. If these are good models, then it should be possible to describe actual till deposition as some combination of these end members. 


\section{MODEL-DATA RELATIONS: TILL GHARAGTER- ISTICS}

Taking the characteristics of the southern Laurentide till units in order as listed above, I now argue that all are consistent with the deforming-bed end member, but some are inconsistent or less consistent with basal-transport models.

\section{Tills are matrix-dominated}

Both deforming-bed and basal-transport models predict matrix-dominated tills under conditions that may have obtained along the southern margin of the Laurentide ice sheet. Many of the tills were deposited by ice that advanced down proglacial lake basins and incorporated fine-grained sediments to form matrix-dominated tills (e.g. Mickelson and others, 1981, 1983). Clast abrasion is known to occur in and beneath deforming diamictons (MacClintock and Dreimanis, 1964; Boulton and others, 1974; Clarke, 1987), which would promote the matrix phase at the expense of clasts; however, abrasion also occurs within deforming basal ice (Weertman, 1968) and between bedrock and clasts in ice (Hallet, 1979).

\section{Tills commonly lack observable deformation indicators (folds, boudinage, etc.)}

A lack of deformation structures in tills is consistent with an undeformed bed or with a bed deformed to very large strains. As shown by Boulton (1987), folds and other strain indicators are possible only with small cumulative strains; they are homogenized when strains become large enough to affect ice flow significantly. Alternatively, it may be that some deformation structures exist in tills but are not observed because the tills are so homogeneous.

\section{Tills exhibit sharp basal contacts with unde- formed or weakly deformed sub-till sediments}

Relatively sharp basal-till contacts and undeformed, weak sub-till beds are more likely with a deforming-bed origin for tills than with a rigid-bed origin, contrary to the proposals of Kemmis (1981, 1986), Sharpe (1986), and Clayton and others $(1987,1989)$. This is based on several lines of evidence:

the high basal velocities and low shear stresses of the ice lobes that deposited these till sheets seem to require a melted, saturated bed with high water pressure. To achieve the inferred ice velocities by sliding without bed deformation would have required higher water pressures than to achieve the same velocity with sliding plus bed deformation. An increase in water pressure decreases sediment strength. Thus, absence of till deformation requires higher water pressures, softer sub-till sediments, and greater probability of sub-till deformation than does the presence of till deformation (Fig. 2);

this effect is heightened in some cases by the position of the till. In a water-saturated, permeable solid such as till, the pore-water pressure generally

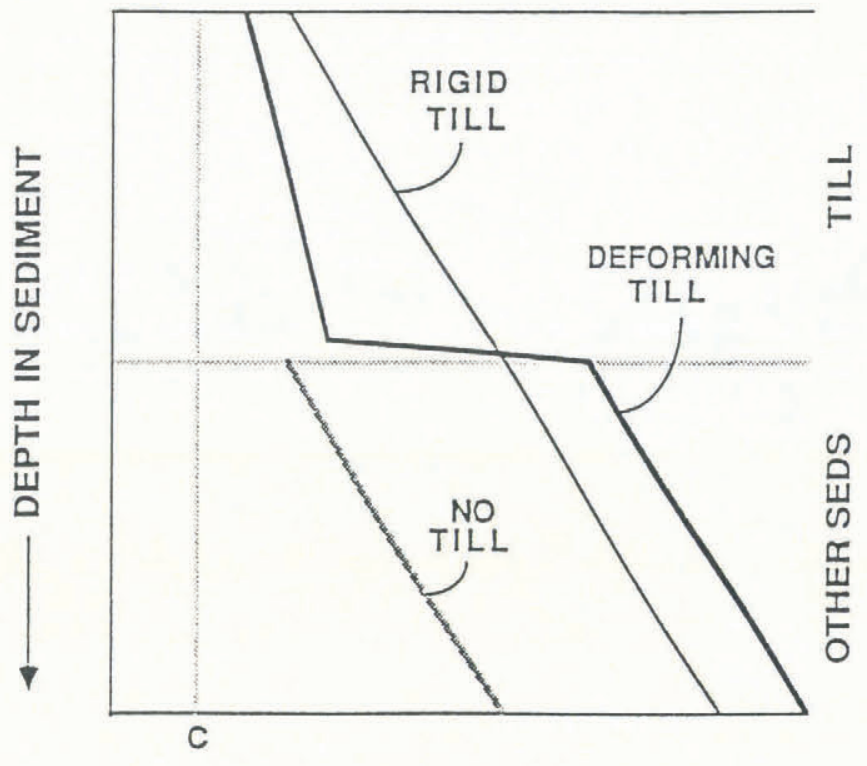

\section{SEDIMENT STRENGTH}

Fig. 2. Schematic diagram showing resistance of watersaturated subglacial sediments to deformation for specified basal ice velocity. Sediment strength is $\tau *=\mathcal{N} \tan \phi+C$, where $C$ is sediment cohesion, $\tan \phi$ is internal friction, and $\mathcal{N}$ is effective pressure (overburden pressure - water pressure). I assume here that $\mathcal{N}$ increases linearly with depth, and that dilation causes "deforming till" to be softer than rigid till, reducing tan $\phi$ and $C$ (Boulton and others, 1974; Alley and others, 1987b). Rigid till requires smaller $\mathcal{N}$ than deforming till for specified velocity (to allow faster sliding over rigid till than over deforming till), which causes sediments beneath rigid till to be softer than beneath deforming till. If the till is carried in basal ice, then the - low effective pressure needed for rapid sliding occurs at the top of the sub-till sediments, further weakening them as shown in the NO-TILL case.

increases downward more slowly than does the overburden pressure (unless there is strong upward water flow, something that is unlikely, although not impossible, beneath ice sheets). Sediment strength increases with this difference between the overburden and pore-water pressures, called the effective pressure. Thus, sediment strength generally should increase downward beneath a glacier (e.g. Boulton and Hindmarsh, 1987; Alley, 1989b). If the sediment now composing a till sheet were carried to its location in ice, then prior to deposition the subtill sediments were closer to the glacier bed, had higher water pressure, and were thus more likely to deform than if the same till sediments were transported subglacially (Fig. 2);

rapid strain causes sediment to dilate, soften, and deform readily. If the strain rate is too low, the sediment collapses, strengthens, and ceases to deform. This positive feed-back tends to localize the transition from deforming to non-deforming sediment at the depth where downward-increasing effective pressure causes the strain rate to fall to the minimum needed to maintain dilation, yielding a 
sharp base to deformed sediments (Alley and others, 1987b; Boulton and Hindmarsh, 1987). This base may be faulted under some circumstances (Boulton and Hindmarsh, 1987; Alley, 1989b);

because ice and sediment transport are linked in both the deforming-bed and basal-transport models, a slowing of ice velocity toward the ice front in an ablation zone will cause a decrease in sediment transport resulting in sediment deposition along flow, unless transport switches to meltwater streams. Essentially, a decrease in basal shear stress or water pressure toward the glacier toe will cause a downglacier rise in the base of the deforming till, causing deposition. If such till deposition occurs, it may form a sharp contact with underlying materials, and will protect those materials from deformation unless further ice advance places them in a region of extending and eroding flow. Such deposition from the base of a deforming layer will occur by "lodgement" in a process entirely analogous to lodgement from moving ice. "Lodged" clasts then would be abraded (MacClintock and Dreimanis, 1964) by clasts in the till deforming over them. It seems possible that such "lodgement" could produce any of the features (ploughing of clasts through underlying sediments (Clark and Hansel, 1989) and bulletstones), often believed to record lodgement from ice.

\section{Tills are overconsolidated}

Strong overconsolidation is unlikely beneath any thin, fast-moving ice lobe, but some overconsolidation is possible with a deforming bed, and is more likely than with a rigid bed. If channelized water reaches the bed of an ice sheet moving on a deforming bed (a likely occurrence if moulins drain surface meltwater to the bed), the channels will lower the water pressure in their vicinity (Fig. 3) and allow overconsolidation (e.g. Weert-

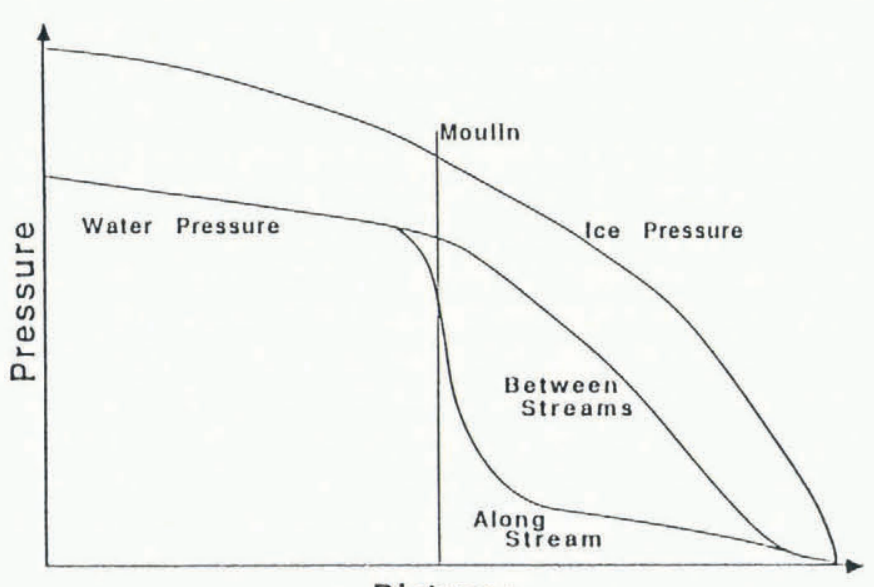

Distance

Fig. 3. Subglacial channelized flow lowers effective pressure in and close to channels, giving the "along-stream" profile. If channels are sufficiently close together, between-stream regions disappear and overconsolidation of all subglacial sediments occurs. man, 1972; Shoemaker, 1986; Alley, 1988b, paper in preparation); if channels are spaced sufficiently close together, all sediments across an ablation zone may become overconsolidated. Retreat of the ablation zone over previously deposited sediments would then allow overconsolidation of large areas. Because a given velocity can be achieved at lower water pressure if the bed deforms than if the bed is rigid, the rigid-bed case suggests higher water pressures and less overconsolidation than the deforming-bed case. Alternatively, the overconsolidation may be post-depositional (e.g. from desiccation) and thus unrelated to glacial processes.

\section{Tills sometimes contain sorted sediments, some with primary depositional features}

Attenuation of folds of sorted sediment incorporated into a deforming bed from below may destroy evidence of the fold before destroying evidence of the sorted sediment, allowing sorted interbeds in tills as stringers or deformed or undeformed blocks (Boulton, 1987). However, primary depositional features may be destroyed in such interbeds.

The presence of unconsolidated or poorly consolidated clasts of sand or other sediments in tills has been cited as evidence against pervasive deformation (Clayton and others, 1989), under the assumption that such features must be destroyed rapidly by pervasive till deformation but could be preserved if such clasts were frozen in the ice. Pervasive deformation certainly does cause abrasion from clast-clast or clast-bed interactions (MacClintock and Dreimanis, 1964; Boulton and others, 1974). However, it is unclear to what extent this requires bulk crushing and rapid disaggregation of weak clasts as opposed to breakage of small protuberances through stress concentrations, especially considering the striking softness of some deforming subglacial sediments (Boulton and others, 1974; Boulton and Hindmarsh, 1987). The apparent persistence of distinguishable sorted interbeds through folding and boudinage (Boulton, 1987) suggests that such sorted clasts may be expected in a deformation till.

In any case, the non-intuitive nature of some deforming-bed processes (e.g. undeformed beds beneath tills providing good evidence for, rather than against, till deformation) should lead us to a skeptical view of the intuitive argument that soft-sediment clasts cannot exist in a deforming bed. Both Elson (1989) and Hicock and others (1989) have suggested that soft-sediment clasts are possible in deforming tills. Because such clasts are most common near the base of the tills, they may have been incorporated quite locally shortly before deposition, possibly during ice retreat. If so, then they may not have experienced as much cumulative strain as the average material in the till.

Channels near the ice margin may allow incorporation of sorted sediments with primary sedimentary structures ("mini-eskers") into a deforming subglacial diamicton. As shown in Figure 4, theoretical considerations (Alley, 1988a) suggest that a channel may cut into a till beneath the ablation zone of a deforming-bedded glacier. Channels are opened by summer meltwaters and closed by creep (of ice or till) in the winter. Such creep closure may trap sorted sediments from a waning channel. It is possible that fabrics in till near such a channel deposit 


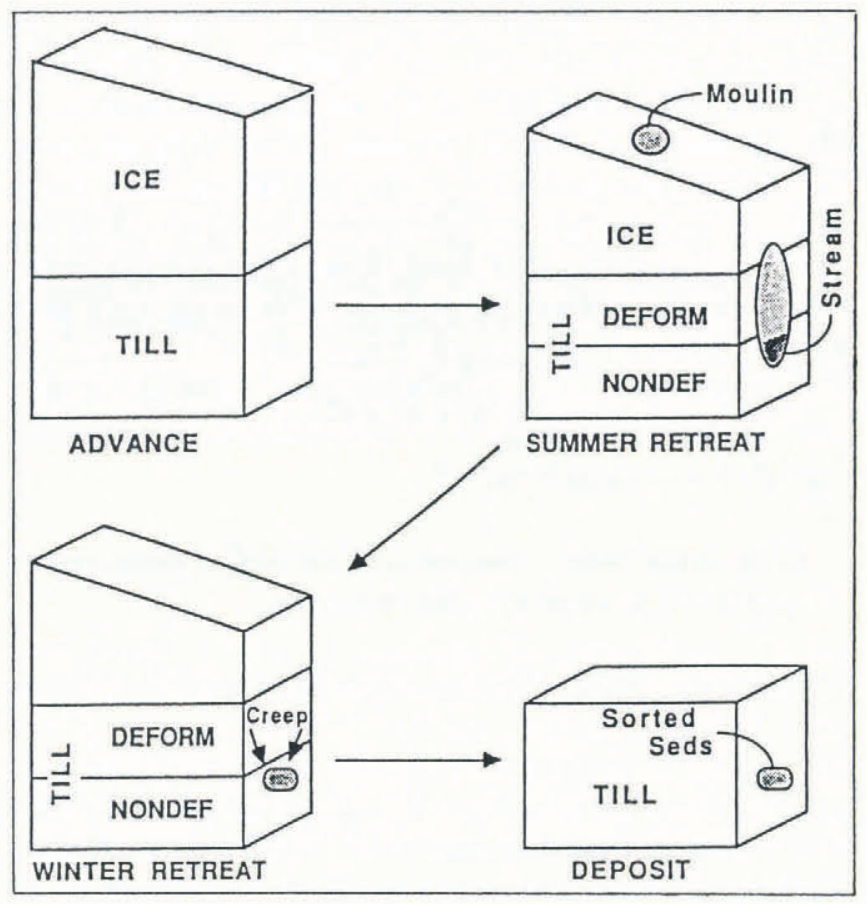

Fig. 4. Hypothetical origin of sorted sediments in deformation till. During ice retreat, a till homogenized during advance experiences deposition (non-deformation, or "nondef" in the figure) from its base, and moulin-fed channels form sorted sediments during the summer. During the winter, channel flow wanes and sediment creeps in over the sorted sediments, forming a sorted "mini-esker" in the till.

would reflect transverse sediment creep into the channel, although continuing ice flow may re-orient the fabrics parallel to ice flow. Such continuing ice flow and till deformation may totally destroy the sorted sediments, form a flat, truncated top on them, or leave them unaffected, depending on the depth to which it occurs. If occurring beneath a retreating glacier, temporal changes in ice flow between years make any of these possible. Smart (1990) presented evidence for the existence of such channel deposits in deformation till in front of and beneath Trapridge Glacier, and suggested that rapid drainage of water stored beneath the glacier may contribute to their formation (also see Eyles and others, 1982; Johnson and Hansel, 1990).

As summarized by Shaw (1985), basal melt-out tills and lodgement tills may include sorted sediments. However, the sorted sediments in melt-out tills are likely to occur as interbedded layers between tills, and may be draped over large clasts or developed in scours beneath boulders. Such features are not typical of the till members under consideration here. Stratified channel fillings in a lodgement till are likely to show truncated, flat tops (Eyles and others, 1982; Shaw, 1985), and might be expected to undergo some ice-contact deformation of the primary sedimentary structures. Creep of debris-laden ice toward such channels might orient fabrics toward the channel that would be preserved during basal melt-out, especially if occurring beneath stagnant ice so that no along-flow deformation and fabric formation occurs. However, because is is thought to be some orders of magnitude harder than deforming subglacial sediments, such channel-creep fabric formation will develop more slowly for ice than for tills.

Our knowledge of the formation of sorted tills in modern environments, and of the occurrence of such sediments in southern Laurentide till sheets, is limited. Careful study of sorted sediments in tills seems warranted and may provide an insight into till origins. At present, it appears that available observations of sorted sediments in southern Laurentide till sheets are consistent with basal and subglacial models.

6 and 7. Tills are characterized by uniform matrix properties, and occur as sheet-like deposits $\approx 1-$ $10 \mathrm{~m}$ thick and several hundred to a few thousand square kilometers

Uniformity and lateral continuity of deposits are not obvious outputs of basal or subglacial models, but seem possible under both. For the subglacial model, we have proposed that a seismically detected layer beneath Ice Stream B, West Antarctica, is a deforming diamicton (e.g. Alley and others, 1986). That layer is seismically relatively uniform over about $10 \times 10 \mathrm{~km}$ near one site, and over a similar area at a second observation site about $200 \mathrm{~km}$ downstream (Rooney and others, 1987, 1988); we infer (near-) continuity and uniformity over an area similar to or larger than the area of the southern Laurentide till sheets under consideration.

It thus appears that the characteristics of the southern Laurentide till sheets discussed above do not provide unequivocal evidence of their origin, although they are more consistent with deforming-bed transport than with basal transport. The discussion of sediment fluxes that follows will lead to a similar conclusion.

\section{MODEL-DATA RELATIONS: SEDIMENT FLUXES}

Comparison of estimated sediment fluxes for the southern Laurentide till sheets with model predictions of those fluxes for different hypotheses offers great opportunities for distinguishing transport mechanisms. Neither data nor hypotheses are sufficient at present for unequivocal results, but some ideas can be eliminated and others strengthened.

In addition to the characteristics cited above, the southern Laurentide till sheets are observed to be compositionally and texturally distinct, and to contain significant far-traveled material (i.e. material that has been transported tens of kilometers or more rather than reworked from underlying tills and transported kilometers or less; Harris and others, 1974; Johnson, 1976; Wickham and Johnson, 1981; Acomb and others, 1982; Johnson and others, 1985; Wickham and others, 1988). Were the till sheets formed predominantly by recycling of older tills, they would lack the pronounced compositional and textural differences observed. Indeed, in some places in Illinois the basal or downstream part of a till sheet appears to have characteristics intermediate between those of an underlying till and those normal for that till sheet, and this is interpreted as a large contribution of reworking to a till composition normally dominated by material transported 
out of the Lake Michigan basin (e.g. Wickham and others, 1988).

Based on this, let us assume that $50 \%$ of the material in a till sheet $50 \mathrm{~km}$ long and $2 \mathrm{~m}$ thick was transported to its present position from up-glacier of the head of that till sheet by ice moving at $500 \mathrm{ma}^{-1}$. Possible transport mechanisms include a regelation layer (Kemmis, 1981), a thicker layer of debris-rich basal ice, and a deforming bed.

As noted above, regelation is the process of pressure melting and refreezing in which the heat of fusion for melting is supplied by the heat of fusion released by adjacent freezing; it involves essentially no net melting or freezing (Bates and Jackson, 1980). At the glacier bed, the basal shear stress causes pressure to be higher and the melting point to be lower on the upstream side of a bump than on the downstream side; ice melts on the upstream side, and water flows around the bump and refreezes on the downstream side, with the heat released by refreezing conducted back through the bump to allow further melting. Because of the requirement of heat conduction back through the bump, regelation is efficient only for very small bumps, typically a few millimeters or less in size; ice traverses larger bumps through enhanced creep. Debris may be trapped in ice during refreezing, but only in the millimeters-thick regelation layer (Kamb and LaChapelle, 1964; Weertman, 1964). Thicker debris-rich basal layers may be formed by net basal freeze-on or by tectonic processes (folding or shearing of debris into the ice, possibly to include tectonic duplication of regelation layers), but regelation acting by itself cannot produce thick debris-rich layers.

For the regelation model (Kemmis, 1981), if we assume $5 \%$ debris by volume (Sugden and John, 1976, p. $161)$ in a $10 \mathrm{~mm}$ thick regelation layer, then to transport enough material into a region to form $50 \%$ of a deposit $50 \mathrm{~km}$ long and $2 \mathrm{~m}$ thick with $25 \%$ porosity from ice moving at $500 \mathrm{~m} \mathrm{a}^{-1}$ would require over $100000 \mathrm{a}$, far longer than the 100-1000 a allowed by data. Raising the debris concentration to $100 \%$ and the thickness to $50 \mathrm{~mm}$, both too high to be likely, would still not supply the inferred till fluxes, especially if it is remembered that the till sheets can reach $10 \mathrm{~m}$ or more rather than the $2 \mathrm{~m}$ assumed here. This casts serious doubt on the hypothesis that regelation acting alone is responsible for the till sheets.

Basal transport could move large quantities of material long distances. For example, the basal $4.83 \mathrm{~m}$ of ice in the Byrd Station ice core from West Antarctica contains $14 \%$ by weight rock debris (Gow and others, 1979), which would produce about $0.5 \mathrm{~m}$ of till on melting. Ice flow of $500 \mathrm{~m} \mathrm{a}^{-1}$ (versus the basal velocity of $0-8 \mathrm{~m} \mathrm{a}^{-1}$ at Byrd Station; Whillans, 1983) with the observed debris thickness and concentration at Byrd Station would allow sufficient debris transport to account for the observed tillsheet chronology. However, fast-moving ice generates much heat from viscous dissipation (friction) and is likely to undergo basal melting rather than freezing-on, with significant debris entrainment limited to freezing-on in slow-moving areas and to tectonic entrainment or freezing-on in a narrow zone near the glacier toe (Whillans, 1978; Alley and others, 1987a, 1989).

The southern Laurentide till sheets appear to have been deposited downstream of fast-moving ice streams or ice lobes, perhaps similar to the modern ice streams of West Antarctica (Hughes and others, 1985). We have calculated that the debris in the basal ice at Byrd Station probably would melt out of the ice during passage down Ice Stream D (Alley and others, 1989); simple analogy suggests that rapid flow down Lake Michigan would have removed any significant thickness of basal debris in the ice before it left the lake basin. If the tills of Illinois do contain abundant sediments from the Lake Michigan basin, then a basal-transport model would require rapid debris entrainment in an area where basal melting and debris loss would be expected. It thus seems unlikely, though certainly not impossible, that basal-transport processes could have produced the observed till sheets.

In comparison, subglacial transport yields the appropriate debris flux for deposition of the southern Laurentide till sheets naturally. The till flux beneath a glacier with a pervasively deforming bed is $\alpha h_{\mathrm{b}} u_{\mathrm{b}}$, where $h_{\mathrm{b}}$ is the deforming thickness, $u_{\mathrm{b}}$ is the velocity at the top of the deforming layer (and is likely to be close to the ice velocity, $u_{\mathrm{i}}$; Alley, 1989b), and $\alpha$ depends on till thickness and water pressure and varies from about 0.1 to 0.5 (Alley, $1989 \mathrm{~b})$. Assuming $u_{\mathrm{b}}=u_{\mathrm{i}}$, the interesting comparison is between the ice velocity and the ice-advance velocity of the toe, $u_{\mathrm{a}}$. If $u_{\mathrm{a}}>\alpha u_{\mathrm{b}}$, then erosion must occur at the toe of the glacier to maintain a constant deforming thickness $h_{\mathrm{b}}$ during advance. (Without erosion near the toe during advance, the deforming layer will be spread over a longer and longer distance and must become thinner and thinner.) If $u_{\mathrm{a}}=\alpha u_{\mathrm{b}}$, then neither erosion nor deposition occurs and, if $u_{\mathrm{a}}<\alpha u_{\mathrm{b}}$, deposition occurs. Behind the toe, deposition from the base of the deforming layer would be likely in regions of compressing flow (velocity decreasing down-glacier), and erosion would be likely in regions of extending flow (velocity increasing down-glacier; Alley and others, 1987a).

For subglacial deformation to transport a constantthickness layer of till $50 \mathrm{~km}$ with an ice velocity of $500 \mathrm{ma}^{-1}$ requires time $100 \alpha^{-1}$, or between 200 and $1000 \mathrm{a}$, similar to the time allowed based on geological evidence. During rapid advance (e.g. southward along Lake Michigan), erosion of proglacial sediments would occur, incorporating local materials preferentially into the base of the till until mixed upward at some unknown rate. As advance slowed (e.g. in Illinois), deposition would begin. Ice stagnation or retreat would leave the lubricating layer as a basal till sheet. Notice that if ploughing or sliding reduce $\alpha$ without increasing debris flux in the ice, as suggested by Beget (1986), then debris transport seems to fall below that required by observations.

It thus appears that the stratigraphic and glaciological characteristics associated with the southern Laurentide till sheets (points 8-13, above) favor a deforming-bed origin. Nonetheless, certain complications prevent us from drawing firm conclusions. If the materials in the till members that are supposed to have been transported at least tens of kilometers by glaciers were actually delivered in some other manner (say by fluvial or lacustrine processes acting between ice advances) and reworked locally, then smaller sediment fluxes would be compatible with the evidence of till sheets. In contrast, if moulin-fed channels or thrusting of debris to the surface near the glacier toe removed significant quantities of sediment from 
the basal tills that had been delivered basally or subglacially, then debris transport must have been higher than calculated above to account for the observed deposits. There is a clear need for quantitative studies to determine how much material was transported how far and how fast by the ice sheets.

Total glacial transport of debris from the Laurentide region over the $\approx 3 \mathrm{Ma}$ of recent glaciation has been estimated as from $25 \mathrm{~m}$ (Flint, 1971; based on undeniably glacial sediment) to $200 \mathrm{~m}$ (Bell and Laine, 1985; including marine sediments of appropriate age off North America), or about $0.01-0.1 \mathrm{~mm} \mathrm{a}^{-1}$. However, glaciers were absent during a significant fraction of this period, and large areas of the ice sheets were frozen to their beds or thawed but moving only slowly, and thus did little geomorphic work (Sugden, 1978). It thus seems likely that the active regions achieved erosion and transport of $0.1-$ $1 \mathrm{~mm} \mathrm{a}^{-1}$ of sediment. We have calculated that an erosion rate of $0.4 \mathrm{~mm} \mathrm{a}^{-1}(\alpha=0.5)$ to a bit less than $0.1 \mathrm{~mm} \mathrm{a}^{-1}$ $(\alpha=0.1)$ averaged over the West Antarctic catchment area of Ice Stream B is enough to supply a steady, $6 \mathrm{~m}$ thick deforming layer with $u_{\mathrm{b}}=500 \mathrm{~m} \mathrm{a}^{-1}$ (Alley and others, 1987b). Thus the debris fluxes expected from a deforming-bed model for the southern Laurentide ice sheet are consistent with estimated modern fluxes.

\section{DISGUSSION}

The information summarized above shows that neither field observations nor model development are sufficiently advanced to allow unequivocal identification of the mechanism(s) of erosion, transport, and deposition of the till sheets on the southern margin of the Laurentide ice sheet. Dominance by uniform matrix and lack of deformation indicators are equally possible with basal and subglacial transport models. Sharp basal contacts with weak underlying sediments and overconsolidation may be possible with basal transport, but are more likely with subglacial, deforming-bed processes. Rates of sediment transport required to deposit the till sheets in the time allowed by geological evidence are much larger than likely in a regelation layer and are larger than expected theoretically for basal transport in a thicker basal layer of frozen-on or sheared-in debris, but are the same as expected from the deforming-bed model. Based on this, the deforming-bed model clearly should be favored, but uncertainty remains.

Among the basal-transport models, regelation can largely be discounted. Lodgement also has some problems; as noted by Hicock and others (1989), soft-sediment clasts probably would not survive being smeared on to a rigid or nearly rigid bed while melting at the ice base. However, if deposition occurred by basal transport, stagnation, and subsequent ice melt-out, we might expect to see evidence of the associated dewatering; this merits further investigation.

Determining the transport mechanism(s) unambiguously for southern Laurentide tills may prove difficult, but should be possible. Clear data on quantity and distance of glacial transport over specified time would be valuable. Careful study of geometry and internal structures of sorted sediments contained in till and of the till containing them may provide useful evidence, with special attention to whether the sorted sediments commonly show evidence of basal melt-out, whether they are channel features with uniformly truncated tops (suggesting lodgement origin of tills), or whether the adjacent tills show transverse fabrics suggestive of sediment creep into channels. For clast-rich tills, clast-clast interactions are likely to cause abrasion and attrition more rapidly than for similar clasts within basal ice. If this can be quantified, then measured downstream attrition of clasts may reveal the transport mode. However, it is unlikely that this will be a sensitive indicator for the matrix-rich tills under consideration here. Hicock and others (1989) have suggested that local indicators of deformation (e.g. disturbed fabrics, irregular stone-pavement surfaces) and careful studies of fissility may prove useful. With all of these possibilities, special care must be taken to distinguish those characteristics of the till sheets reflecting conditions under the body of the ice sheet from those characteristics reflecting modification near the ice margin during deglaciation.

It is clear that much work remains to elucidate fully the origin of the southern Laurentide till sheets. Pending such work, deforming-bed transport should be the leading hypothesis, but basal transport and lodgement or melt-out should be retained as alternate working hypotheses.

\section{ACKNOWLEDGEMENTS}

I thank C. Bentley, P. Clark, S. Hicock, T. Lowell, D. Mickelson, J. Shaw, an anonymous reviewer, and members of Geology 875 (spring 1987 at the University of Wisconsin under Professor Bentley with Professor Mickelson) for helpful suggestions. This research was funded in part by the U.S. National Science Foundation under grants DPP-8716016 and DPP-8915995.

\section{REFERENCES}

Acomb, L.J., D. M. Mickelson and E. B. Evenson. 1982. Till stratigraphy and late glacial events in the Lake Michigan lobe of eastern Wisconsin. Geol. Soc. Am. Bull., 93(4), 289-296.

Alley, R. B. 1988a. Glacial deposits as (lack of) evidence for deforming beds. Society of Economic Paleontologists and Mineralogists Annual Midyear Meeting Abstracts (Columbus, Ohio) V, 2.

Alley, R.B. 1988b. Subglacial water system on an unconsolidated bed. [Abstract.] Eos, 69(44), 1210.

Alley, R. B. 1989a. Water-pressure coupling of sliding and bed deformation: I. Water system. f. Glaciol., 35(119), 108-118.

Alley, R. B. 1989b. Water-pressure coupling of sliding and bed deformation: II. Velocity-depth profiles. F. Glaciol., 35(119), 119-129.

Alley, R.B., D. D. Blankenship, C. R. Bentley and S.T. Rooney. 1986. Deformation of till beneath Ice Stream B, West Antarctica. Nature, 322(6074), 57-59.

Alley, R. B., D. D. Blankenship, S. T. Rooney and C. R Bentley. 1987a. Continuous till deformation beneath ice sheets. International Association of Hydrological Sciences Publication 170 (Symposium at Vancouver 1987 - The 
Physical Basis of Ice Sheet Modelling), 81-91.

Alley, R.B., D. D. Blankenship, C. R. Bentley and S.T. Rooney. 1987b. Till beneath Ice Stream B. 3. Till deformation: evidence and implications. 7. Geophys. Res., 92(B9), 8921-8929.

Alley, R. B., D. D. Blankenship, S. T. Rooney and C. R. Bentley. 1989. Sedimentation beneath ice shelves - the view from Ice Stream B. Mar. Geol., 85(2/4), 101-120.

Attig, J. W., D. M. Mickelson and L. Clayton. 1989. Late Wisconsin landform distribution and glacier-bed conditions in Wisconsin. Sediment. Geol., 62, 399-405.

Bates, R. L. and J. A. Jackson, eds. 1980. Glossary of geology. Second edition. Falls Church, VA, American Geophysical Institute.

Beget, J.E. 1986. Modeling the influence of till rheology on the flow and profile of the Lake Michigan lobe, southern Laurentide ice sheet, U.S.A. .7. Glaciol., 32(111), 235-241.

Bell, M. and E. P. Laine. 1985. Erosion of the Laurentide region of North America by glacial and glaciofluvial processes. Quat. Res., 23(2), 154-174.

Blake, E. W. and G. K. C. Clarke. 1989. In situ bed strain measurements beneath a surge-type glacier. [Abstract.] Eos, 70(43), 1084.

Blankenship, D. D., C. R. Bentley, S. T. Rooney and R. B. Alley. 1987. Till beneath Ice Stream B. 1. Properties derived from seismic travel times. 7. Geophys. Res., 92(B9), 8903-8911.

Boulton, G.S. 1987. A theory of drumlin formation by subglacial sediment deformation. In Menzies, J. and J. Rose, eds. Drumlin Symposium. Proceedings of the Drumlin Symposium ... Manchester 16-18 September 1985. Rotterdam, etc., A. A. Balkema, 25-80.

Boulton, G.S. and R. C. A. Hindmarsh. 1987. Sediment deformation beneath glaciers: rheology and geological consequences. 7. Geophys. Res., 92(B9), 9059-9082.

Boulton, G.S., D. L. Dent and E.M. Morris. 1974. Subglacial shearing and crushing, and the role of water pressures in tills from south-east Iceland. Geogr. Ann., 56A(3-4), 135-145.

Brown, N. E., B. Hallet and D. B. Booth. 1987. Rapid soft bed sliding of the Puget glacial lobe. 7. Geophys. Res., 92(B9), 8985-8997.

Clark, P. U. and A. K. Hansel. 1989. Clast ploughing, lodgement and glacier sliding over a soft glacier bed. Boreas, 18(3), 201-207.

Clark, P. U. and R.J. Lillie. 1989. Estimates of subglacial sediment strength, southern Laurentide ice sheet. [Abstract.] Eos, 70(43), 1084.

Clayton, L., J. T. Teller and J. W. Attig, Jr. 1985. Surging of the southwestern part of the Laurentide ice sheet. Boreas, 14(3), 235-241.

Clayton, L., J.W. Attig and D. M. Mickelson. 1987. Evidence against deformable bed material as the cause of southern Laurentide ice streams and surges. INQUA 1987 Programme with Abstracts, 145.

Clayton, L., D. M. Mickelson and J.W. Attig. 1989. Evidence against pervasively deformed bed material beneath rapidly moving lobes of the southern Laurentide ice sheet. Sediment. Geol., 62(3-4), 203-208.

Dreimanis, A. 1989. Tills: their genetic terminology and classification. In Goldthwait, R. P. and C. L. Matsch, eds. Genetic classification of glacigenic deposits. Rotterdam,
A. A. Balkema, 17-83.

Echelmeyer, K. and W. Zhongxiang. 1987. Direct observation of basal sliding and deformation of basal drift at sub-freezing temperatures. 7. Glaciol., 33(113), 83-98.

Elson, J. A. 1989. Comment on glacitectonite, deformation till, and comminution till. In Goldthwait, R.P. and C. L. Matsch, eds. Genetic classification of glacigenic deposits. Rotterdam, A. A. Balkema, 85-88.

Engelhardt, H. F., W. D. Harrison and B. Kamb. 1978. Basal sliding and conditions at the glacier bed as revealed by bore-hole photography. 7. Glaciol., 20(84), 469-508.

Eyles, N., J. A. Sladen and S. Gilroy. 1982. A depositional model for stratigraphic complexes and facies superimposition in lodgement till. Boreas, 11(4), 317-333.

Fahnestock, M. and N. Humphrey. 1988. Borehole water level measurements, Columbia Glacier, AK. [Abstract.] Ice 86, 25-26.

Flint, R. F. 1971. Glacial and Quaternary geology. New York, etc., John Wiley and Sons.

Gow, A.J., S. Epstein and W. Sheehy. 1979. On the origin of stratified debris in ice cores from the bottom of the Antarctic ice sheet. 7. Glaciol., 23(89), 185-192.

Hallet, B. 1979. A theoretical model of glacial abrasion. $\mathcal{J}$. Glaciol., 23(89), 39-50.

Harris, K. L., S. R. Moran and L. Clayton. 1974. Late Quaternary stratigraphic nomenclature, Red River Valley, North Dakota and Minnesota. North Dakota Geol. Surv. Misc. Ser. 52.

Hicock, S. R., R.J. Kristjansson and D. R. Sharpe. 1989. Carbonate till as a soft bed for Pleistocene ice streams on the Canadian shield north of Lake Superior. Can. 7 . Earth Sci., 26(11), 2249-2254.

Hughes, T.J., G.H. Denton and J. L. Fastook. 1985. The Antarctic ice sheet: an analog for Northern Hemisphere paleo-ice sheets? In Woldenberg, M.J., ed. Models in geomorphology. Boston, etc., Allen and Unwin, 25-72.

Johnson, W.H. 1976. Quaternary stratigraphy in Illinois: status and current problems. In Mahaney, W. C., ed. Quaternary stratigraphy of North America. Stroudsburg, PA, Dowden, Hutchinson and Ross, Inc., 161-196.

Johnson, W.H. and A.K. Hansel. 1990. Multiple Wisconsinan glacigenic sequences at Wedron, Illinois. 7. Sediment. Petrol., 60(1), 26-41.

Johnson, W.H., A. K. Hansel, B.J. Socha, L. R. Follmer and J.M. Masters. 1985. Depositional environments and correlation problems of the Wedron Formation (Wisconsinan) in northeastern Illinois. Ill. State Geol. Surv. Guideb. Ser. 16.

Kamb, B. and E. LaChapelle. 1964. Direct observation of the mechanism of glacier sliding over bedrock. $\mathcal{J}$. Glaciol., 5(38), 159-172.

Kemmis, T.J. 1981. Importance of the regelation process to certain properties of basal tills deposited by the Laurentide ice sheet in Iowa and Illinois, U.S.A. Ann. Glaciol., 2, 147-152.

Kemmis, T.J. 1986. Properties of sediment beds beneath Quaternary tills in the mid-continent U.S.A. [Abstract.] Eos, 67(44), 947.

MacClintock, P. and A. Dreimanis. 1964. Reorientation of till fabric by overriding glacier in the St. Lawrence Valley. Am. J. Sci., 262(1), 133-142. 
Mathews, W.H. 1974. Surface profiles of the Laurentide ice sheet in its marginal areas. F. Glaciol., 13(67), 37-43.

Meier, M.F. 1989. Relation between water input, basal water pressure, and sliding of Columbia Glacier, Alaska, U.S.A. (Abstract.) Ann. Glaciol., 12, 214-215.

Mickelson, D. M., L.J. Acomb and C. R. Bentley. 1981. Possible mechanism for the rapid advance and retreat of the Lake Michigan lobe between 13,000 and 11,000 years BP. (Abstract.) Ann. Glaciol., 2, 185-186.

Mickelson, D. M., L. Clayton, D. S. Fullerton and H. W. Borns, Jr. 1983. The Late Wisconsin glacial record of the Laurentide ice sheet in the United States. In Wright, H.E., Jr, ed. Late Quaternary environments of the United States. Vol. 1. The Late Pleistocene. Minneapolis, MN, University of Minnesota Press, 3-37.

Rooney, S. T., D. D. Blankenship, R.B. Alley and C.R. Bentley. 1987. Till beneath Ice Stream B. 2. Structure and continuity. 7. Geophys. Res., 92(B9), 8913-8920.

Rooney, S. T., D. D. Blankenship, R.B. Alley and C.R. Bentley. 1988. Seismic-reflection profiling of a widespread till beneath Ice Stream B, West Antarctica. (Abstract.) Ann. Glaciol., 11, 210.

Sharpe, D. R. 1986. Field tests of the deformable bed concept. [Abstract.] Eos, 67(44), 946.

Shaw, J. 1985. Subglacial and ice marginal environments. In Ashley, G. M., J. Shaw and N. D. Smith, eds. Glacial sedimentary environments. Short course No. 16. Tulsa, OK, Society of Economic Paleontologists and Mineralogists, 7-84.

Shaw, J., D. Kvill and B. Rains. 1989. Drumlins and catastrophic subglacial floods. Sediment. Geol., 62(3-4), 177-202.

Shoemaker, E. M. 1986. Subglacial hydrology for an ice sheet resting on a deformable aquifer. F. Glaciol., 32(110), 20-30.
Smart, C. C. 1990. Subglacial flow systems in hard and soft-bedded glaciers. Abstracts with Programs, 25th Annual Meeting, Northeastern Section, Geological Society of America, 71.

Sugden, D. E. 1978. Glacial erosion by the Laurentide ice sheet. F. Glaciol., 20(83), 367-391.

Sugden, D. E. and B. S. John. 1976. Glaciers and landscape: a geomorphological approach. London, Edward Arnold.

Weertman, J. 1964. The theory of glacier sliding. 7 . Glaciol., 5(39), 287-303.

Weertman, J. 1968. Diffusion law for dispersion of hard particles in an ice matrix that undergoes simple shear deformation. 7. Glaciol., 7(50), 161-165.

Weertman, J. 1972. General theory of water flow at the base of a glacier or ice sheet. Rev. Geophys. Space Phys., 10(1), 287-333.

Whillans, I. M. 1978. Erosion by continental ice sheets. $\mathcal{F}$. Geol., 86(4), 516-524.

Whillans, I. M. 1983. Ice movement. In Robin, G. de Q, ed. The climatic record in polar ice sheets. Cambridge, etc., Cambridge University Press, 70-77.

Wickham, S.S. and W.H. Johnson. 1981. The Tiskilwa Till, a regional view of its origin and depositional processes. Ann. Glaciol., 2, 176-182.

Wickham, S. S., W.H. Johnson and H.D. Glass. 1988. Regional geology of the Tiskilwa Till Member, Wedron Formation, northeastern Illinois. Ill. State Geol. Surv. Circ. 543.

Wright, H. E., Jr. 1973. Tunnel valleys, glacial surges, and subglacial hydrology of the Superior lobe, Minnesota. Geol. Soc. Am. Mem. 136, 251-276.

The accuracy of references in the text and in this list is the responsibility of the author, to whom queries should be addressed. 